\title{
Reaction of Sweet Cassava Genotypes to Xanthomonas phaseoli pv. manihotis From Three Regions of Brazil
}

\author{
K. R. Aquiles ${ }^{1,2}$, Eder Marques $^{3}$, J. V. Malaquias ${ }^{4}$, J. K. A. Mattos ${ }^{1}$, J. F. Fialho ${ }^{4}$, E. A. Vieira ${ }^{4}$ \& C. H. Uesugi ${ }^{1}$ \\ ${ }^{1}$ University of Brasilia, Brasilia, DF, Brazil \\ ${ }^{2}$ Emater, Brasilia, DF, Brazil \\ ${ }^{3}$ UPIS Integrated Colleges, Planaltina, DF, Brazil \\ ${ }^{3}$ Embrapa Cerrados, Planaltina, DF, Brazil \\ Correspondence: E. A. Vieira, Embrapa CPAC, BR-020, km 18, s/n-Planaltina, Brasília, DF, 73310-970, Brazil. \\ Tel: 55 61-3448-4433. E-mail: eduardo.alano@embrapa.br
}

\author{
Received: January 30, $2021 \quad$ Accepted: February 28, $2021 \quad$ Online Published: March 15, 2021 \\ doi:10.5539/jas.v13n4p64 URL: https://doi.org/10.5539/jas.v13n4p64
}

The research is financed by National Council for scientific and Technological Development (CNPq), Banco do Brasil Foundation (FBB) and Coordination for the Improvement of Higher Education Personnel (CAPES).

\begin{abstract}
Xanthomonas phaseoli pv. manihotis $(\mathrm{Xpm})$ is the causal agent of Cassava Bacterial Blight (CBB), one of the most important cassava diseases. The aim of this study was to evaluate the susceptibility of sweet cassava genotypes to strains of Xpm from three different geographic regions of Brazil in greenhouse conditions. The inoculation of 14 genotypes of cassava was made by cutting leaflets using scissors previously soaked in a bacterial suspension with $1 \times 10^{8} \mathrm{UFC} \mathrm{ml}^{-1}$ and also by inserting a soaked toothpick into the bud of the oldest leaf. The results showed significant differences when the cassava genotypes were individually evaluated in relation to the Xpm strains used; however, the relationship between cassava genotypes and Xpm strains was significant for wilt symptom. The UnB 1111 strain was more aggressive than the UnB 1386 strain based on the average value of the reaction grade, showing the variation that exists between the bacterial isolates from different regions. Considering the reaction of cassava germplasm's resistance to the three strains used in the study, the BGMC 434 genotype was the only one classified as resistant based on the average reaction grade. The genotypes BGMC 753, BGMC 1289, BGMC 982 and the elite clones BRS 396, BRS 397, BRS 398, 259/08 and BRS 399 were classified as moderately resistant, which indicates the possibility of recommending them for disease favorable regions.
\end{abstract}

Keywords: bacteriosis, genetic resistance, Manihot esculenta Crantz, plant breeding, variability

\section{Introduction}

Cassava, Manihot esculenta Crantz (Euphorbiaceae), is a perennial shrub grown mainly in tropical countries. It is important in the food security of these populations due to its robustness, which is reflected in the capacity to store high amounts of starch in its roots under conditions in which other species would not even survive (Filgueiras \& Homma, 2016). Brazil is the $5^{\text {th }}$ largest world producer of cassava (FAOSTAT, 2019), with an area of 1,362,185 hectares and a production of 18,994,242 tons (IBGE, 2020). However, the productive potential of the crop can be limited by the attack of pests and diseases, so protection against these is a crucial element in the production of cassava (Fukuda et al., 2002; Ceballos et al., 2004).

One of the main diseases that affect the crop in cultivation areas in the Center South region of Brazil is the bacteriosis known as Cassava Bacterial Blight (CBB) (Fukuda et al., 2002) caused by Xanthomonas phaseoli pv. manihotis (Xpm) (Constantin et al., 2016). In conditions favorable to the development of the disease, with sudden temperature fluctuations between day and night above $10{ }^{\circ} \mathrm{C}$ and annual precipitation above $1200 \mathrm{~mm}$, root yield losses can vary from 30 to $100 \%$ (Anjos et al., 2013).

The first symptoms of bacteriosis in the Cerrado region of Central Brazil usually appear at the beginning of the rainy season, after the dry season, and show their maximum at the peak of the rainy season. The infected plants 
initially show wilting on the young leaves, irregular watery spots on the leaflets, symptoms of a systemic nature, such as canker and exudation of gum on the stems and descending death of the leaves, culminating in the death of the plant. The bacterium invades the plant systemically through the xylem vessels, which are responsible for transporting water and mineral salts (Hillocks \& Wydra, 2002; Anjos et al., 2013).

The spread of the pathogen in the same planting area occurs through rain, which disperses bacterial cells present in the exudation of infected plants to healthy plants. The penetration of bacteria in healthy plants occurs through natural openings and wounds present in the leaves. The spread of the bacterium over long distances occurs through the planting of contaminated seeds, especially in new areas where the disease is not yet present. When the propagation material is contaminated by the bacterium Xpm, sprout losses of more than $25 \%$ can occur (López, 2002; Anjos et al., 2013).

Differences in virulence were found between Xpm isolates in Africa and Latin America, which showed different speeds in the appearance of bacteriosis symptoms, due to the variation in aggressiveness between the isolates (Restrepo et al., 2004; Portz et al., 2006; Nery-Silva et al., 2007; Banito et al., 2010; Ogunjobi et al., 2010, Martin et al., 2017). Recent transcriptome studies indicate that the various responses of accessions to Xpm may result from the action of TALEs-Transcription Activator Like Effectors (Ramirez et al., 2020).

Since the Xpm bacterium has a systemic habit, curative control methods are not viable. The use of resistant varieties is the most efficient control method, even in climatic conditions favorable to the development of the epidemic, considering that they suffer fewer losses from the disease (Fukuda et al., 2002; Ceballos et al., 2004; Nery-Silva et al., 2007, Martin et al., 2017).

The objective of the study was to evaluate the reaction of genotypes of sweet cassava to isolates of Xanthomonas phaseoli pv. manihotis from three geographic regions of Brazil under greenhouse conditions.

\section{Method}

\subsection{Cassava Accessions Used}

To carry out the study, six accessions of table cassava (Table 1) conserved in the Regional Collection of Cassava of the Cerrado (BGMC) were selected, and these were: (i) three varieties recommended for cultivation in the Federal District and Surrounding Region, BGMC 982 (IAPAR 19), BGMC 753 (IAC 576-70) and BGMC 1289 (BRS Moura) (Fialho et al., 2009; Vieira et al., 2009, 2011b, 2018); (ii) the variety recommended for cultivation in the region of the Recôncavo Baiano and the Coastal Tablelands, BGMC 1398 (BRS Dourada); (iii) the 'Taquari' variety (BGMC 434) used as a standard for bacteriosis resistance; (iv) the 'Vassourinha' variety (BGMC 962) used as a standard for susceptibility to bacteriosis. In addition to these six accessions, eight elite sweet cassava clones from the Embrapa Cerrados genetic improvement program were also used in the study (BRS 399, BRS 396, BRS 397, 215/08, 259/08, 83/08, BRS 398 and 26/08).

Table 1. Genotypes and genealogy of cassava accessions evaluated in this study

\begin{tabular}{ll}
\hline Genotypes & Genealogy \\
\hline $26 / 08$ & BGMC 751 × BGMC 753 \\
$83 / 08$ & BGMC 751 × BGMC 753 \\
$215 / 08$ & BGMC 751 × BGMC 753 \\
$246 / 08$ & BGMC 751 × BGMC 753 \\
$259 / 08$ & BGMC 1289 × BGMC 753 \\
BRS 396 & BGMC 1289 × BGMC 753 \\
BRS 397 & BGMC 1289 × BGMC 753 \\
BRS 398 & BGMC 1218 open pollination \\
$450 / 08$ & BGMC 1218 open pollination \\
BRS 399 & BGMC 1218 open pollination \\
BGMC 753 (IAC 576-70) & IAC Ouro do Vale open pollination \\
BGMC 982 (IAPAR 19) & Landrace (local variety) \\
BGMC 1289 (BRS Moura) & Landrace (local variety) \\
BGMC 1398 (BRS Dourada) & Landrace (local variety) \\
'Taquari' (BGMC 434) & Landrace (local variety) \\
'Vassourinha' (BGMC 962) & Landrace (local variety) \\
\hline
\end{tabular}


The plants were obtained by the method of rapid propagation (Rodrigues et al., 2008) with some adaptations, where approximately $10 \mathrm{~cm}$ seedlings were planted in plastic vases of 2-liter capacity, filled with substrate that served as a propagation chamber, which aims to increase the temperature and relative humidity inside the chamber, stimulating the production of shoots. After the shoots reached approximately $10 \mathrm{~cm}$ in height, they were cut and placed for rooting in sterile water. The rooted shoots were transplanted individually into plastic bags suitable for seedlings, which were $10 \mathrm{~cm}$ wide, $20 \mathrm{~cm}$ high and $0.07 \mathrm{~cm}$ thick; these were filled with an autoclaved mixture composed of red latosol, sand, tanned bovine manure and vermiculite, in the following proportions 2:1:1:1, in addition to which 40 liters of the mixture and 100 grams of the NPK fertilizer formulation (4-14-8) were added. The transplanted seedlings were placed on concrete benches inside the greenhouse for acclimatization.

The vigorous seedlings of the accessions produced by the method of rapid propagation were selected uniformly, with height between 25 and $30 \mathrm{~cm}$. These were transplanted into plastic vases of $2 \mathrm{~L}$ capacity, using the autoclaved substrate in the proportions previously described. After transplantation, the seedlings were placed on concrete benches inside the greenhouse. The greenhouse was covered with a shade screen with $30 \%$ shade, in order to reduce the direct incidence of sunlight on the plants and the temperature inside the greenhouse. One week after transplantation, plants were inoculated with the three strains of Xpm used in the study, plus the control with distilled water.

\subsection{Plant Pathogenic Bacteria Tested}

Three strains of Xpm from three regions of Brazil were used: UnB 1386 (Planaltina-DF), UnB 1152 (Manaus-AM) and UnB 1111 (Paranavaí-PR), preserved in the collection of the Bacteriology Laboratory of the Department of Phytopathology of the Institute of Biological Sciences of the University of Brasília.

\subsection{Bacterial Inoculation}

The bacterial suspension was prepared using new Xpm cultures, grown in 523 medium (Kado \& Heskett, 1970) for $48 \mathrm{~h}$. The strains of the bacterium were diluted in sterile distilled water and the suspensions measured in a spectrophotometer with a wavelength of $550 \mathrm{~nm}$ until absorbance 0.350 was obtained, which corresponds to the concentration of $1 \times 10^{8} \mathrm{CFU} \mathrm{ml}^{-1}$.

The inoculation of the leaves was performed by prior immersion of small, sterile scissors in the bacterial suspension and subsequent cutting of three leaflets in different leaves. Sterile toothpicks were used to inoculate the stem, immersed in the bacterial suspension for 10 minutes. One toothpick per plant was inserted into the axial side of the oldest leaf.

The monitoring of the temperature and relative humidity of the air inside the greenhouse was performed by a datalogger (ITLOG-75), programmed to record the hourly parameters.

\subsection{Evaluation of Cassava Accessions to Cassava Bacterial Blight}

The assessment was made based on the scale of Ramos and Takatsu (1987), with modifications where the symptoms of the aerial part were measured through the quantification of leaf spots and wilting, the systemic infection was measured through the quantification of regrowth with or without descending death, appearance of bacterial pus on the stems and descending death (Table 2). The symptoms of the aerial part were evaluated individually according to the variation in the speed of appearance over the weeks (Table 2). For the intervals of variations in the onset of symptoms, scores were assigned, which ranged from 1 to 5 (Table 2).

The relationship between the symptoms was determined by the average of the notes of the symptoms of spot (S), wilt (W) and complex of symptoms of systemic nature (CSSN), which is called degree of reaction (DR). After obtaining the averages of the grades represented by the DR, the classification of the reaction of the cassava accessions to Xpm was performed using the variations of the DR (Table 2). 
Table 2. Scales of grades attributed to the different intervals of appearance of leaf spots, wilt and symptoms of systemic nature, in plants inoculated with Xanthomonas phaseoli pv. manihotis (adapted from Ramos \& Takatsu, 1987) and resistance and susceptibility ranges, based on the degree of reaction (DR) related to the symptoms of bacteriosis

\begin{tabular}{ll}
\hline Grades & Strain symptoms \\
\hline 1 & No symptoms of the disease \\
2 & Appearance of leaf spots typical of the disease from 4 weeks after inoculation \\
3 & Appearance of leaf spots typical of the disease in the 3rd week after inoculation \\
4 & Appearance of leaf spots typical of the disease in the 2nd week after inoculation \\
5 & Appearance of leaf spots typical of the disease in the 1st week after inoculation \\
\hline Grades & Wilt symptoms \\
\hline 1 & No symptoms of the disease \\
2 & Appearance of wilted leaves typical of the disease from the 5th week after inoculation \\
3 & Appearance of wilted leaves typical of the disease in the 4th week after inoculation \\
4 & Appearance of wilted leaves typical of the disease in the 3rd week after inoculation \\
5 & Appearance of wilted leaves typical of the disease in the 2nd week after inoculation \\
\hline Grades & Symptoms of a systemic nature \\
\hline 1 & No symptoms of the disease \\
2 & Partial recovery without descending death from the apex of the plant \\
3 & Partial recovery with descending death from the apex of the plant \\
4 & Presence of bacterial exudation along the stem without or with partial recovery \\
5 & Descending death of the plant, with the presence of exudate and without partial recovery \\
\hline DR & Classification regarding resistance and susceptibility, based on the degree of reaction (DR) \\
\hline $1.0-2.0$ & Resistant (R) \\
$2.1-3.0$ & Moderately resistant (MR) \\
\hline
\end{tabular}

\subsection{Statistical Analysis}

The experimental design used was completely randomized (CDR), in a factorial scheme composed of 14 genotypes of cassava and three strains of Xpm, with five replicates for each treatment. The data were first transformed into the square root of $X$ and later submitted to joint variance analysis. The means were compared using the Tukey test at 5\% probability of error. All statistical analyses were performed with the aid of the SAS statistical program (Statistical Analysis System-version 9.1.3) (SAS, 2006).

\section{Results}

The results of the joint analysis of variance revealed the existence of significant differences at $5 \%$ probability of error, in relation to the average scores of the individual symptoms of S, W, CSSN and DR, between the genotypes evaluated for the three strains of Xpm used in the study (Table 3). This revealed the existence of genetic variability regarding the resistance of genotypes to $\mathrm{Xpm}$. As for strains, only significant differences were detected at $5 \%$ probability of error between strains for $\mathrm{W}$ and DR, showing that the strains evaluated show different degrees of aggressiveness when these characters are considered (Table 3). However, the presence of significant interaction between the genotype and strain effects was detected only for W. This indicates that the order of classification of the genotypes regarding the symptoms of $\mathrm{W}$ was influenced by the strain effect, as the accessions presented different responses to the strains. This can be explained by genetic variations in both genotypes and strains. 
Table 3. Summary of the analysis of joint variance and coefficient of variation (CV\%) of the symptoms of spots (S), wilt (W), complex of symptoms of a systemic nature (CSSN) and the degree of reaction (DR) of 14 genotypes of table cassava inoculated with three isolates of Xanthomonas phaseoli pv. manihotis

\begin{tabular}{llllll}
\hline \multirow{2}{*}{$\mathbf{S V}^{*}$} & \multirow{2}{*}{$\mathbf{D F}^{* *}$} & \multicolumn{4}{c}{$\mathbf{M S}^{* * *}$} \\
\cline { 3 - 6 } & & $\mathbf{S}$ & $\mathbf{W}$ & $\mathbf{C S S N}$ & $\mathbf{D R}$ \\
\hline Genotypes (G) & 13 & $0.0269^{\circ}$ & $0.0770^{\circ}$ & $1.5108^{*}$ & $0.4599^{*}$ \\
Isolates (I) & 2 & 0.0008 & $0.5066^{\circ}$ & 0.1203 & $0.0821^{*}$ \\
Interaction G x I & 26 & 0.00032 & $0.0586^{\circ}$ & 0.0386 & 0.0105 \\
Residue (R) & 168 & 0.0022 & 0.0147 & 0.0876 & 0.0129 \\
Total & 209 & & & & \\
\hline CV (\%)**** & & 2.32 & 9.32 & 24.37 & 6.58 \\
\hline
\end{tabular}

Note. $* \mathrm{SV}=$ Sources of Variation; $* * \mathrm{DF}=$ Degrees of Freedom; $* * * \mathrm{MS}=$ Mean Square $* * * * \mathrm{CV}=$ Coefficient of Variation.

The average temperature in the evaluation period was $23.9^{\circ} \mathrm{C}$, with a maximum of $30.2^{\circ} \mathrm{C}$ and a minimum of $16.4{ }^{\circ} \mathrm{C}$. The average relative air humidity was $86.8 \%$ in the period of the research, with a maximum of $99.9 \%$ and a minimum of $49.9 \%$.

Through the average of the degree of reaction (DR), it was possible to separate the cassava genotypes into four groups of resistance to Xpm. Considering the three strains of Xpm, a difference was observed regarding the reaction of the cassava genotypes, which allowed them to be grouped into resistance classes (Table 4).

Table 4. Comparison of averages of 14 genotypes of table cassava inoculated with three isolates of Xanthomonas phaseoli pv. manihotis, by means of individual symptoms of wilt (W), spot (S), systemic symptom complex (CSSN) and the degree of reaction (DR) and the classification as to the degree of resistance in resistant (R), moderately resistant (MR), moderately susceptible (MS) and susceptible (S), through individual symptoms

\begin{tabular}{|c|c|c|c|c|c|c|c|}
\hline \multirow{2}{*}{ Genotype } & \multicolumn{3}{|c|}{$\mathbf{W}$} & \multicolumn{3}{|c|}{ UnB 1386, UnB 1111 and UnB 1152} & \multirow{2}{*}{ General Reaction } \\
\hline & UnB 1386 & UnB 1111 & UnB 1152 & $\mathbf{S}$ & CSSN & DR & \\
\hline BGMC 962 & $4.58 \mathrm{aA}^{*}$ & $5.00 \mathrm{aA}$ & $5.00 \mathrm{aA}$ & $4.33 \mathrm{ab}^{* *}$ & $4.20 \mathrm{a}$ & $4.45 \mathrm{a}$ & $\mathrm{S}$ \\
\hline $83 / 08$ & $4.80 \mathrm{aA}$ & $4.41 \mathrm{aA}$ & $4.00 \mathrm{abcA}$ & $4.00 \mathrm{c}$ & $2.25 \mathrm{~b}$ & $3.46 \mathrm{~b}$ & MS \\
\hline BGMC 1398 & $4.58 \mathrm{aA}$ & $5.00 \mathrm{aA}$ & $5.00 \mathrm{aA}$ & $4.58 \mathrm{a}$ & $2.62 \mathrm{~b}$ & $3.96 \mathrm{ab}$ & MS \\
\hline $26 / 08$ & $4.16 \mathrm{abA}$ & $4.80 \mathrm{aA}$ & $4.58 \mathrm{abA}$ & $4.00 \mathrm{c}$ & $2.04 \mathrm{~b}$ & $3.42 \mathrm{~b}$ & MS \\
\hline BRS 397 & $3.96 \mathrm{abA}$ & $3.96 \mathrm{aA}$ & $3.17 \mathrm{bcA}$ & $4.08 \mathrm{bc}$ & $1.25 \mathrm{c}$ & $2.86 \mathrm{c}$ & MR \\
\hline BRS 396 & $3.96 \mathrm{abA}$ & $4.41 \mathrm{aA}$ & $3.53 \mathrm{abcA}$ & $4.00 \mathrm{c}$ & $1.14 \mathrm{c}$ & $2.86 \mathrm{c}$ & MR \\
\hline BGMC 1289 & $3.96 \mathrm{abA}$ & $3.96 \mathrm{aA}$ & $3.17 \mathrm{bcA}$ & $4.00 \mathrm{c}$ & $1.00 \mathrm{c}$ & $2.69 \mathrm{c}$ & MR \\
\hline BGMC 753 & $3.76 \mathrm{abcA}$ & $4.58 \mathrm{aA}$ & $3.57 \mathrm{abcA}$ & $4.00 \mathrm{c}$ & $1.17 \mathrm{c}$ & $2.86 \mathrm{c}$ & MR \\
\hline $215 / 08$ & $3.50 \mathrm{abcB}$ & $4.58 \mathrm{aA}$ & $2.96 \mathrm{cB}$ & $4.00 \mathrm{c}$ & $1.00 \mathrm{c}$ & $2.69 \mathrm{c}$ & MR \\
\hline BRS 398 & $3.39 \mathrm{abcA}$ & $4.20 \mathrm{aA}$ & $3.17 \mathrm{bcA}$ & $4.00 \mathrm{c}$ & $1.00 \mathrm{c}$ & $2.66 \mathrm{c}$ & MR \\
\hline BRS 399 & $2.96 \mathrm{bcA}$ & $3.57 \mathrm{aA}$ & $3.57 \mathrm{abcA}$ & $4.00 \mathrm{c}$ & $1.00 \mathrm{c}$ & $2.59 \mathrm{c}$ & MR \\
\hline BGMC 982 & $2.79 \mathrm{bcB}$ & $4.16 \mathrm{aA}$ & $2.96 \mathrm{cB}$ & $4.00 \mathrm{c}$ & $1.06 \mathrm{c}$ & $2.59 \mathrm{c}$ & MR \\
\hline $259 / 08$ & $2.53 \mathrm{cB}$ & $3.57 \mathrm{aA}$ & $4.00 \mathrm{abcA}$ & $4.00 \mathrm{c}$ & $1.25 \mathrm{c}$ & $2.72 \mathrm{c}$ & MR \\
\hline BGMC 434 & $1.35 \mathrm{dA}$ & $1.93 \mathrm{bA}$ & $1.77 \mathrm{dA}$ & $4.00 \mathrm{c}$ & $1.00 \mathrm{c}$ & $2.00 \mathrm{~d}$ & $\mathrm{R}$ \\
\hline Overall average & 3.59 & 4.16 & 3.61 & 4.07 & 1.57 & 2.99 & \\
\hline
\end{tabular}

Note. $*$ = Means followed by uppercase letters in the horizontal, and lowercase letters in the vertical, differ from each other at $5 \%$ probability of error by the Tukey means comparison test; ** = Average values for the three isolates used in this experiment.

Considering the DR average in relation to the three strains used in the study, the BGMC 962 genotype was classified as susceptible to the disease, in line with its previous classification by Vieira et al. (2011a). In turn, the BGMC 1398, 26/08 and 83/08 genotypes were classified as moderately susceptible by means of the mean DR value (Table 4).

The analysis of the averages of the degree of reaction (DR) for the three Xpm isolates, considering the 14 cassava 
genotypes, allowed us to establish the difference in aggressiveness between the strains used in the study (Table $5)$. From the comparison of the averages of the degree of reaction, strain UnB 1111 was more aggressive than strain UnB 1386. Strain UnB 1152 showed intermediate aggressiveness in relation to strains UnB 1111 and UnB 1386.

Table 5. Comparison of means of three strains of Xanthomonas phaseoli pv. manihotis by means of wilt (W) and degree of reaction (DR), evaluated in 14 genotypes of table cassava

\begin{tabular}{lll}
\hline Strains & W & DR \\
\hline UnB 1111 & $4.12^{*} \mathrm{a}^{* *}$ & $3.10 \mathrm{a}$ \\
UnB 1152 & $3.57 \mathrm{~b}$ & $2.96 \mathrm{ab}$ \\
UnB 1386 & $3.53 \mathrm{~b}$ & $2.86 \mathrm{~b}$ \\
\hline
\end{tabular}

Note. $*=$ Statistical analysis performed with transformed means for square root of $\mathrm{X}$ and untransformed data presented in the table; $* *=$ Means followed by distinct letters in the column differ from each other, at $5 \%$ probability of error by the Tukey means comparison test.

\section{Discussion}

The genotypes BGMC 753, BRS 396, BRS 397, 215/08, BGMC 1289, BRS 398, 259/08, BGMC 982 and BRS 399 were classified as moderately resistant, based on the mean DR value. The accessions BGMC 982 and BGMC 753 had already shown resistance to bacteriosis in an experiment conducted in Planaltina-DF (Vieira et al., 2011a). The accession BGMC 434 was classified as resistant, according to the average values of DR considering the three strains (Table 4).

The differences in the genetic constitution of the cassava genotypes are responsible for the classification variation after inoculation with Xpm strains from different regions. It is especially important to carry out studies in regions where cassava cultivars will be produced, when the objective is to select and recommend materials resistant to Xpm. The existence of differences in the classification of cassava genetic constitutions, using Xpm strains under greenhouse conditions, has already been reported (Wydra et al., 2004; Restrepo et al., 2004; Nery-Silva et al., 2007; Banito et al., 2010). In a similar study, the occurrence of a significant interaction between 26 isolates of Xpm and 17 genotypes of cassava was detected after the inoculation of the plant stems measured under the area of the disease progress curve (Restrepo et al., 2004). However, the interaction of isolates x cassava genotypes after leaf inoculation was not significant. Banito et al. (2010) used four highly virulent Xpm strains from different African regions and 24 cassava genotypes among local and improved varieties. After the inoculation of the plant stems, they found that the interaction of isolates $x$ cassava genotypes was significant, with six groups of different genotypes being useful for identifying the pathotype, differing from the result obtained in this study for the DR.

Nery-Silva et al. (2007) used the same scale of visual symptom scores of aerial parts used in this study and evaluated ten cultivars of sweet cassava and eight clones of bitter cassava, using two strains of Xpm. They observed that five varieties of sweet cassava demonstrated differences regarding resistance classification, and no variety of manioc showed variation, being all classified as resistant to disease. In other studies, there were also differences in the classification of cassava genotypes regarding the resistance group after inoculation of Xpm isolates. After inoculation of the stem of 111 improved cassava genotypes, with suspensions $10^{7} \mathrm{UFC} \mathrm{mL}^{-1}$ of four stems of Xpm in greenhouse conditions, Wydra et al. (2004) revealed that based on the average of the area below the disease progress curve, 16 genotypes were resistant, 26 showed moderate resistance and 69 susceptibility. Banito et al. (2010) reported that 11 cassava genotypes were classified as resistant, four as moderately resistant and nine as susceptible after the inoculation of the stems of 24 local cassava varieties with four virulent strains of Xpm.

When evaluating 1090 cassava accessions, composed of traditional varieties and improved in terms of the reaction of cassava germplasm to three strains of Xpm under greenhouse conditions, Ogunjobi et al. (2010) reported that of the 490 local varieties used in the study, $30.1 \%$ were highly susceptible, $12.3 \%$ susceptible, $24.3 \%$ tolerant and $14.3 \%$ resistant. Among the 600 improved cassava accessions, $4.3 \%$ were highly susceptible, $36.6 \%$ tolerant, $30.1 \%$ resistant and $11.1 \%$ showed high resistance. The differences in the classification of cassava accessions from the average reaction grade (DR), with the use of Xpm strains in the inoculation of leaves and stems, can be explained by the genetic variability between cassava accessions and Xpm isolates from different locations. 
The cassava genotypes 215/08, BGMC 982 and 259/08 showed significant interaction with the Xpm strains used in the study for the symptom of W. When inoculated with strain UnB 1111, the plants of genotypes 215/08 and BGMC 982 showed quicker appearance of wilted leaves than when inoculated with strains UnB 1386 and UnB 1152. When inoculated with strains UnB 1111 and UnB 1152, plants of genotype 259/08 showed a greater speed in the appearance of wilted leaves than when inoculated with the strain UnB 1386. The variation in the speed of appearance of withered leaves of a given cassava genotype with the inoculation of different strains of Xpm can be explained by the genetic variability between the cassava genotypes and the difference in aggressiveness between the Xpm strains. Analyzing the capacity of colonization of vascular tissue after inoculation with strains of Xpm in genotypes of sweet and bitter cassava, Nery-Silva et al. (2007) found differences in the percentage of systemic infection with the variation of the Xpm strain.

Considering the 14 cassava genotypes, the analysis of the mean of the symptom of $\mathrm{W}$ for the three isolates of $X p m$ allowed us to establish differences in the speed of symptom manifestation throughout the evaluation period. From the comparison of averages for $\mathrm{W}$, the cassava genotypes inoculated with strain UnB 1111 showed a higher rate of onset of wilted leaves than when inoculated with strains UnB 1152 and UnB 1386. A factor that may have influenced the greater speed of manifestation of the symptom of $\mathrm{W}$ in cassava seedlings inoculated with strain $\mathrm{UnB} 1111$ is a high capacity for colonization of vascular tissue, which obstructs the passage of water and nutrients, due to the genetic characteristic of the strain. In a similar study, assessing the percentage of systemic stem infection after the inoculation of eight bitter cassava genotypes with two strains of Xpm, Nery-Silva et al. (2007) found that the Uberlândia strain was more efficient in colonizing vascular tissues than the Lavras strain.

In similar studies, it was possible to verify the difference in aggressiveness between the strains of Xpm from different regions. Through the evaluation of 21 isolates of Xpm in relation to aggressiveness, using the "Verdinha" variety that is highly susceptible to the pathogen, it was possible to determine six isolates of Xpm as more aggressive than the others (Portz et al., 2006). Nery-Silva et al. (2007) evaluated 10 cultivars of sweet cassava in relation to the reaction to Xpm from the region of Lavras-MG and Uberlândia-MG. Based on the average values of the visual symptoms of the aerial part, percentage of systemic infection and percentage of defoliation, they reported the occurrence of differences in aggressiveness between the isolates employed in the study, the Lavras-MG isolate being more aggressive than that of Uberlândia-MG for the three characteristics evaluated.

Comparable results were described by Banito et al. (2010), when evaluating the aggressiveness of four Xpm isolates from different African regions after inoculation of the plant stems of 24 local and improved varieties of cassava. Those authors found that the Uganda 12 and GSPB 2507 strains were more aggressive than the GSPB 2511 and GSPB 2506 strains. Ogunjobi et al. (2007) evaluated the aggressiveness of $72 \mathrm{Xpm}$ isolates in six cassava accessions. Of all the Xpm isolates, $10 \%$ were not aggressive for the 'Isu' variety; however, $58.5 \%$ were highly aggressive for the same variety. As for clones 30572 and $94 / 0430,34 \%$ and $32.7 \%$ of the Xpm isolates were moderately aggressive, respectively. Both clones were resistant to $12.9 \%$ of the tested isolates. Only $44.2 \%$ of the Xpm isolates were highly aggressive to clone 4 (2) 1425, but it was moderately resistant to $45 \%$ of the $X p m$ strains. Clones $96 / 0037$ and 60142 were resistant only to 8.2 and $8.8 \%$ of the Xpm strains, being susceptible to 58.5 and $61.9 \%$ of the strains, respectively.

In the Cote d'Ivoire, in the field, Martin et al. (2017) also observed variation in the aggressiveness of Xpm, suggesting that it is associated with different bacterial strains and different varieties of cassava used in the region, which present different levels of sensitivity to the pathogen. This field experiment also took place under favorable climatic conditions for the pathogen, such as alternate rainy and dry seasons, high humidity and significant temperature oscillations between day and night.

In the present study, the only genotype classified as resistant in terms of the average degree of reaction for the three strains evaluated was accession BGMC 434. The genotypes recommended for cultivation in the Federal District and Surrounding Region, BGMC 753 (IAC 576-070), BGMC 1289 (BRS Moura), BGMC 982 (IAPAR 19) and the elite clones BRS 396, BRS 397, 446/08, 259/08, 215/08 and BRS 399 were classified as moderately resistant to bacteriosis.

\section{Conclusion}

There were significant differences between cassava genotypes and Xpm strains. The UnB 1111 strain was more aggressive than the UnB 1386 strain. The BGMC 434 genotype was the only one classified as resistant in terms of the average degree of reaction for the three strains evaluated, proving its resistance pattern. The cultivars BGMC 753, BGMC 1289, BGMC 982 are already widely used by farmers in the Federal District and Surrounding Region, and they presented as moderately resistant to Xpm for the three strains, as did the elite clones BRS 396, BRS 397, 446/08, 259/08, 215/08 and BRS 399, presenting the potential for cultivation in 
regions where climatic conditions are favorable for the development of the disease.

\section{References}

Anjos, J. R. N., Silva, M. S., Vieira, E., \& Fialho, J. F. (2013). Principais doenças da mandioca no Cerrado. In J. F. Fialho \& E. A. Vieira (Eds.), Mandioca no Cerrado: Orientações técnicas (2nd ed., pp. 61-88). Planaltina: Embrapa Cerrados. Retrieved from https://www.embrapa.br/busca-de-publicacoes/-/publicacao/981357/ mandioca-no-cerrado-orientacoes-tecnicas

Banito, A., Kpémoua, K. E., \& Wydra, K. (2010). Screening of cassava genotypes for resistance to bacterial blight using strain $\times$ genotype interactions. Journal of Plant Pathology, 92(1), 181-186. https://doi.org/ 10.4454/jpp.v92i1.28

Ceballos, H., Iglesias, C. A., Pérez, J. C., \& Dixon, A. G. O. (2004). Cassava breeding: opportunities and challenges. Plant Molecular Biology, 56, 503-516. https://doi.org/10.1007/s11103-004-5010-5

Constantin, E. C., Cleenwerck, I., Maes, B. S., Van Malderghem, C., De Vos, P., \& Cottyn, B. (2016). Genetic characterization of strains named as Xanthomonas axonopodis pv. dieffenbachiae leads to a taxonomic revision of the X. axonopodis species complex. Plant Pathology, 65(5), 792-806. https://doi.org/10.1111/ ppa. 12461

FAOSTAT (Food and Agriculture Organization). (2019). Countries by commodity-Cassava. Retrieved from http://www.fao.org/faostat/en/\#rankings/countries_by_commodity

Fialho, J. F., Vieira, E., Silva, M. S., Paula-Moraes, S. V., Fukuda, W. M. G., Santos Filho, M. O. S., \& Silva, K. N. (2009). Desempenho de variedades de mandioca de mesa no Distrito Federal. Revista Brasileira de Agrociência, 15(1-4), 31-35. https://doi.org/10.18539/cast.v15i1-4.1983

Filgueiras, G. C., \& Homma, A. K. O. (2016). Aspectos socioeconômicos da cultura da mandioca na região norte. In M. S. Modesto Júnior \& R. N. B. Alves (Eds.), Cultura da mandioca: Aspectos socioeconômicos, melhoramento genético, sistemas de cultivo, manejo de pragas e doenças e agroindústria (Chapter 1, pp. 15-48). Brasília, DF: Embrapa. Retrieved from https://www.embrapa.br/busca-de-publicacoes/-/publicacao/ 1056645/aspectos-socioeconomicos-da-cultura-da-mandioca-na-regiao-norte

Fukuda, W. M. G., Silva, S. O., \& Iglesias, C. (2002). Cassava breeding. Crop Breeding and Applied Biotechnology, 2, 617-638. https://doi.org/10.12702/1984-7033.v02n04a18

Hillocks, R. J., \& Wydra, K. (2002). Bacterial, Fungal and Nematode Disease. In R. J. Hillocks, J. M. Thresh, \& A. C. Bellotti (Eds.), Cassava: Biology, Production and Utilization (pp. 261-280). New York: CAB International. https://doi.org/10.1079/9780851995243.0261

IBGE (Brazilian Institute of Geography and Statistics). (2020). Levantamento Sistemático da Produção Agricola-Novembro 2020. Retrieved from https://sidra.ibge.gov.br/home/lspa/brasil

Kado, C. I., \& Heskett, M. G. (1970). Selective media for isolation of Agrobacterium, Corynebacterium, Erwinia, Pseudomonas and Xanthomonas. Phytopathology, 60, 969-976. http://doi.org/10.1094/Phyto-60-969

López, J. (2002). Semilla Vegetativa de Yuca. In B. Ospina \& H. Ceballos (Eds.), La Yuca en el Tercer Milenio: Sistemas Modernos de Produción, Processamiento, Utilização y Comercialización (pp. 49-75). Cali: CIAT. Retrieved from https://cgspace.cgiar.org/bitstream/handle/10568/54117/La_Yuca_en_el_Tercer_Milenio. pdf? sequence $=1 \&$ isAllowed $=\mathrm{y}$

Martin, A. A., Kouabenan, A., Seydou, T., Boni, N., \& Daouda, K. (2017). Geographical distribution and incidence of cassava bacterial blight (Manihot esculenta Crantz) caused by Xanthomonas axonopodis pv. manihotis in two agro-ecological zones of Côte d'Ivoire. Plant Pathology Journal, 16(1), 1-11. https://doi.org/10.3923/ppj.2017.1.11

Nery-Silva, F. A., Fernandes, J. J., Juliatti, F. C., \& Melo, B. (2007). Reação de germoplasma de mandioca a Xanthomonas axonopodis pv. manihots. Semina: Ciências Agrárias, 28(1), 3-10. https://doi.org/ 10.5433/1679-0359.2007v28n1p3

Ogunjobi, A. A., Fagade, O. E., Dixon, A. G. O., \& Bandyopadhyay, R. (2010). Assessment of large population of cassava accessions for resistant to cassava bacterial blight infection in the screen house environment. Journal of Agricultural Biotechnology and Sustainable Development, 2, 87-91. Retrieved from https://academicjournals.org/journal/JABSD/article-full-text-pdf/16A2615614

Portz, L. R., Kuhn, O. J., Franzener, G., \& Stangarlin, J. R. (2006). Caracterização de isolados de Xanthomonas axonopodis pv. manihotis. Acta Scientiarum Agronomy, 28(3), 413-419. https://doi.org/10.4025/ 
actasciagron.v28i3.965

Ramirez, E., Dereepe, A., Benal, A., Szurek, B., \& Lopez, C. (2020). Resistance and susceptibility to Xanthomonas phaseoli pv. manihotis in cassava: A transcriptomic comparison (or two sides of the same coin). Physiological and Molecular Plant Pathology, 112, 1-11. https://doi.org/10.1016/j.pmpp.2020. 101535

Ramos, J. G. A., \& Takatsu, A. (1987). Avaliação da resistência de cultivares de mandioca à bacteriose em Goiás (p. 26). Goiânia: EMGOPA.

Restrepo, S., Velez, C. M., Duque, M. C., \& Verdier, V. (2004). Genetic structure and population dynamics of Xanthomonas axonopodis pv. manihotis in Colombia from 1995 to 1999. Applied and Environmental Microbiology, 70(1), 255-261. https://doi.org/10.1128\%2FAEM.70.1.255-261.2004

Rodrigues, A. R., Alves, J. M. A., Uchôa, S. C. P., Albuquerque, J. A. A., Rodrigues, G. S., \& Barros, M. M. (2008). Avaliação da capacidade de enraizamento, em água, de brotações, ponteiros e estacas herbáceas de clones de mandioca de mesa. Agro@mbiente On-line, 2(1), 37-45. Retrieved from https://revista.ufrr.br/ agroambiente/article/view/163/93

SAS Institute. (2006). Statistical analysis system (Version 9.1.3). Cary: SAS Institute.

Vieira, E. A., Fialho, J. F., Faleiro, F. G., Bellon, G., Fonseca, K. G., Carvalho, L. J. C. B., ... Denke, M. L. (2011a). Characterization of sweet cassava accessions based on molecular, quantitative and qualitative data. Crop Breeding and Applied Biotechnology, 11(3), 232-240. https://doi.org/10.1590/S1984-70332011000 300005

Vieira, E. A., Fialho, J. F., Silva, M. S., Fukuda, W. M. G., \& Santos Filho, M. O. S. (2009). Comportamento de genótipos de mandioca de mesa no Distrito Federal. Revista Ciência Agronômica, 40(1), 113-122. Retrieved from http://ccarevista.ufc.br/seer/index.php/ccarevista/article/view/412/308

Vieira, E. A., Fialho, J. F., Silva, M. S., Paula-Moraes, S. V., Oliveira, C. M., Anjos, J. R. N., ... Guimarães Júnior, R. (2011b). BRS Japonesa: New sweet cassava cultivar for the Distrito Federal region. Crop Breeding and Applied Biotechnology, 11(2), 193-196. https://doi.org/10.1590/S1984-70332011000200014

Vieira, E. A., Fialho, J. F., Júlio, L., Carvalho, L. J. C. B., Dalla Corte, J. L., Rinaldi, M. M., ... Anjos, J. R. N. 2018. Sweet cassava cultivars with yellow or cream root pulp developed by participatory breeding. Crop Breeding and Applied Biotechnology, 18(4), 450-454. https://doi.org/10.1590/1984-70332018v18n4c67

Wydra, K., Zinsou, V., Jorge, V., \& Verdier, V. (2004). Identification of pathotypes of Xanthomonas axonopodis pv. manihotis in Africa and detection of quantitative trait loci and markers for resistance to bacterial blight of cassava. Phytopathology, 94, 1084-1093. https://doi.org/10.1094/PHYTO.2004.94.10.1084

\section{Copyrights}

Copyright for this article is retained by the author(s), with first publication rights granted to the journal.

This is an open-access article distributed under the terms and conditions of the Creative Commons Attribution license (http://creativecommons.org/licenses/by/4.0/). 